\title{
How much of the Caatinga is legally protected? An analysis of temporal and geographical coverage of protected areas in the Brazilian semiarid region
}

\author{
Lucas Peixoto Teixeira, ${ }^{1,} \odot$, Eimear Nic Lughadha ${ }^{2} \oplus$, Marcus Vinicius Chagas da Silva ${ }^{3}($ \\ and Marcelo Freire Moro ${ }^{3 *}$ (1)
}

Received: November 18, 2020

Accepted: January 19, 2021

\begin{abstract}
Tropical dry forests are among the most threatened vegetation types in the world, exposed to even higher deforestation rates than rainforests. The largest tropical dry forest is the Caatinga, in the semiarid Northeast region of Brazil. Home to many endemic species and genera, the Caatinga has lost half of its original vegetation cover and become highly fragmented. Furthermore, the Caatinga is little protected by conservation units and subject to multiple human pressures. Brazil committed to the Convention of Biological Diversity's Strategic Plan for Biodiversity 2011-2020, including the Aichi Biodiversity Targets, requiring protection of $17 \%$ of terrestrial habitats. Using GIS, we quantified the total area of Caatinga encompassed by fully protected and sustainable use reserves. We found that less than $8 \%$ of the Caatinga is legally protected under Brazil's national nature reserve legislation (SNUC law), and only $1.3 \%$ is in reserves with full legal protection. We show that the geographical distribution of reserves is biased, leaving some regions of the Caatinga with very little protection. We conclude that Brazil has not met international conservation commitments with respect to the Caatinga and, despite a recent expansion of the protected area network, only small and unrepresentative portions of the Caatinga are effectively safeguarded.
\end{abstract}

Keywords: Aichi Target 11, Caatinga, CBD, ecoregions, protected areas effectiveness

\section{Introduction}

Brazil is divided in six phytogeographical domains, termed 'biomes' by Instituto Brasileiro de Geografia e Estatística (IBGE 2004). These domains show strong geographical differentiation, both in climate and geomorphology, resulting in diverse and distinctive landscapes and associated flora across Brazil, from the hyperdiverse, hot and humid tropical Amazon to the temperate grasslands of the southern Pampas (IBGE 2004; Zappi et al. 2015).

Among these, the Caatinga Phytogeographical Domain is located in a semiarid region with tropical dry forests and is one of the most threatened domains in the country, having lost half of its original vegetation cover (Antongiovanni et al. 2018). Worldwide, the dry forest biome is undergoing one of the greatest rates of deforestation, faster even than tropical rainforests (Miles et al. 2006). To reduce such human

\footnotetext{
1 Programa de Pós-graduação em Desenvolvimento e Meio Ambiente, Universidade Federal do Ceará, 60455-970, Fortaleza, CE, Brazil 2 Conservation Science Department, Royal Botanic Gardens, Kew, TW9 3AE, Richmond, Surrey, United Kingdom

3 Instituto de Ciências do Mar, Universidade Federal do Ceará, 60165-081, Fortaleza, CE, Brazil

* Corresponding author: marcelomoro@ufc.br
} 
impacts on biodiversity and vegetation, international multilateral environmental agreements include specific targets concerning how much should be protected from each ecosystem. The Convention on Biological Diversity proposed in 2010 a number of conservation targets which are known as 'Aichi Biodiversity Targets for 2020'. These include a number of measures to be taken by governments to safeguard biodiversity by protecting ecosystems, species and genetic diversity (CBD 2010).

The Caatinga Phytogeographical Domain (hereafter Caatinga) is located in Northeastern Brazil and northern Minas Gerais and is the driest of the Brazilian domains, with low rainfall and strong seasonality (Ab'Sáber 1974; Ab'Sáber 2003; Moro et al. 2016). The Caatinga is also subject to periodic strong droughts, where very reduced rainfall occurs across several consecutive years (Nimer 1972). Droughts were historically associated with famine and migration in the region and the Caatinga was socially stigmatized as an area of poverty. This is likely reflected in how society, government and even the scientific community perceived conservation issues in these dry ecosystems. Much of twentieth century conservation focus was on preserving "rainforests". While phytogeographical domains such as the Amazon, Atlantic Forest and Pantanal were recognised as "National Heritage" sites by Brazil's 1988 Federal Constitution, the Caatinga, Cerrado and Pampas Domains were not (Brasil 1988).

Caatinga received little scientific attention during most of the 20th century (Santos et al. 2011; Moro et al. 2015) and influential biologists regarded it as of secondary interest for conservation due to the alleged lack of endemic species of plants or animals (Rizzini 1963; Vanzolini et al. 1980). Towards the end of the 20th century and early in the 21st, an increase in taxonomic and biodiversity studies in the Caatinga began to reveal levels of species richness and endemism higher than previously expected, including endemic plant and animal species and genera (Rodrigues 1996; Sampaio et al. 2002; Rodrigues \& Santos 2008; Zappi et al. 2015; Queiroz et al. 2017; Fernandes et al. 2020). Furthermore, dry forests in general began to attract greater scientific interest, being recognized as important for conservation and biogeography (Pennington et al. 2000; Banda et al. 2016).

Despite recent recognition of the need to conserve representative parts of all Brazilian natural domains, Caatinga has already lost half of its vegetation cover (Brazil Ministry of the Environment 2015), and a significant part of the remaining half has been fragmented and degraded to varying degrees by agriculture, cattle farming, invasive species spread and road construction (Castelletti 2003; Leal et al. 2005; Antongiovanni et al. 2018).

Although long acknowledged as an environmentally heterogeneous region from a geographical perspective (Ab’Sáber 1974), Caatinga was only later recognised as heterogeneous from a biodiversity perspective. An important step forward was the publication in 2002 of a biogeographical map for Caatinga, splitting it in eight "ecoregions" (Velloso et al. 2002), taking into account differences in geomorphology, species composition, and endemism in different areas of Caatinga.

The Convention on Biological Diversity's Aichi biodiversity target 11 states: "By 2020, at least 17 per cent of terrestrial and inland water, and 10 per cent of coastal and marine areas, especially areas of particular importance for biodiversity and ecosystem services, are conserved through effectively and equitably managed, ecologically representative and well-connected systems of protected areas and other effective area-based conservation measures...". Although the quantitative targets for area conserved are most often quoted, it is increasingly recognised that successful achievement of Target 11 will also require consideration of other elements for which numerical values are not included in the wording of the Target (Gannon et al. 2017; Bacon et al. 2019).

In response to Aichi Target 11, Brazil adopted a new national Target 11 that establishes that, "by 2020, at least $30 \%$ of the Amazon, and $17 \%$ of the Caatinga, Cerrado, Atlantic Forest and Pantanal [...] shall be protected under protected areas..." (Brazil - Ministry of the Environment 2015). With the Aichi deadline fast approaching, we undertook a quantitative and qualitative evaluation of progress towards meeting the Aichi target in Caatinga, a phytogeographical domain exclusive to Brazil and home to irreplaceable biodiversity for the protection of which Brazil is uniquely responsible. Specifically, we investigated temporal and geographical coverage of protected areas (PA), which are termed 'Conservation Units' (Unidades de Conservação) under the national system of nature reserves (Sistema Nacional de Unidades de Conservação - SNUC, Lei $\left.{ }^{\circ} 9,981 / 2000\right)$ within the Caatinga, evaluating their coverage by ecoregion.

We also evaluated the degree of protection of each ecoregion by the differing levels of human use restriction applicable to each site by the PA categories recognised in Brazilian law. We applied a quantitative, spatial approach to address two key questions. Firstly, how does current PA coverage of the Caatinga compare to the $17 \%$ targeted? Secondly, to what extent does current PA coverage meet the Aichi requirement for ecological representation in each Caatinga ecoregion? We also applied a more qualitative approach in an attempt to address a third key question: does the current PA network for Caatinga meet the Aichi requirement for effective management?

\section{Materials and methods}

\section{Study area}

Our study area belongs mostly to Brazilian semiarid region and its boundary is determined by eight ecoregions of Caatinga, recognised by Velloso et al. (2002). These 
ecoregions (Fig. 1) extend to all nine states of Brazil's Northeast region and also encompass a small area of Minas Gerais state. The limits of Caatinga proposed by Velloso et al. (Velloso et al. 2002) differ from those recognised by IBGE (2004). Furthermore, Velloso et al.'s (2002) recognition of multiple ecoregions within the Caatinga domain contrasts sharply with the global ecoregion system of Olson et al. (2001) that is more commonly used for evaluating progress towards global targets for protected areas (e.g., Juffe-Bignoli et al. 2014; Bacon et al. 2019) but which treats almost all the Caatinga as a single ecoregion. Velloso et al.'s (2002) classification was preferred for this study because it better reflects growing understanding of the heterogeneity of the Caatinga domain by dividing it into smaller ecoregions, based on the presence of endemic species or genera of animals and plants. These smaller ecoregions within Caatinga provide a more appropriate framework for addressing our second question, concerning ecological representation.

\section{Classification of Protected Areas in Brazilian law}

Brazil's system of nature reserves SNUC was established by a national law passed in 2000 that recognized 12 types of protected areas (Brasil 2000). Each type of PA establishes limits to human activities inside the designated area. Protected areas are usually grouped in two broad classes: Full Protection PAs (Unidade de Conservação de Proteção Integral), where only indirect uses (ecotourism, observation, etc.) are allowed; and Sustainable Use PAs (Unidade de Conservação de Uso Sustentável), in which varying levels of human interference are allowed depending on the specific PA type established by law. In order to address our third question, as to the extent to which existing PAs are effectively managed, we treated the seven PA types which comprise the Sustainable Use class as three groups, separating those with greatest and least legal protection from those with intermediate levels of protection. This resulted in a total of four groups for our analysis, described below in order of decreasing legal protection:

Group I - Full Protection (Unidades de Conservação de Proteção Integral - PI), includes all five types of full protection PA defined by SNUC (Tab. 1). These have the highest level of protection because only indirect use of natural resources is permitted;

Group II - Private Natural Patrimony Reserves (Reservas Particulares do Patrimônio Natural - RPPN). These are private reserves where landowners request public authorities to recognize their land as an official nature reserve. If recognized and declared as a nature reserve, the area receives a stronger level of legal protection than any other type of PA in SNUC's Sustainable Use class;

Group III -Sustainable Use Reserves (Reservas de Uso Sustentável - RUS) with intermediate level of protection. This group comprises all but two of the protected area types in SNUC's Sustainable Use class, the exceptions being RPPN (above) and Environmental Protection Areas (below);
Group IV - Environmental Protection Areas (Área de Proteção Ambiental - APA), a category with extremely low level of protection in Brazilian law. An APA usually encompasses large expanses of land, including agricultural and urban areas. Lands remain private, economic uses are usually allowed to continue, and public supervision is normally light, resulting in low or negligible effectiveness in protecting biodiversity. Such APAs cost little to implement because they do not require the government to purchase land, nor impose strong limits to how landowners use the land. Thus, enormous APAs were established in some Brazilian territories to increase the "amount of protected sites" even though the efficacy for conservation of some of these APAs was and is questionable.

Brazil-wide surveys show that APAs have been subjected to increasing pressures, greater than those reported for other Sustainable Use PAs (those in our Groups II and III) (ICMBIO \& WWF-Brasil 2011). Specifically, APAs are reported to experience exceptionally high and rising levels of pressure from tourism and recreation, from pollution and from human occupation (ICMBIO \& WWF-Brasil 2011). More recently, Brazil-wide surveys showed APAs scoring joint highest for the proportion of their conservation targets which were not at the level of conservation expected/hoped for: 64\%, almost two thirds (ICMBIO \& WWF-Brasil 2017).

\section{Data acquisition}

Geographical data for protected areas were downloaded through the online database available at Brazil's ministry for the environment, Ministério do Meio Ambiente (MMA) website <http://mapas.mma.gov.br/i3geo/datadownload. $\mathrm{htm}>$ at January 3rd, 2018. The database downloaded provided files in shapefile format for all Brazilian PAs officially registered at the "Cadastro Nacional de Unidades de Conservação" (CNUC; MMA - http://mapas.mma.gov. $\mathrm{br} /$ geonetwork/srv/br/metadata.show?id=1250, accessed in January 2018). Files in shapefile format provided us 155 georeferenced polygons (124 PA registrations at CNUC) for PAs and their attribute tables which comprise metadata for each PA, including unique identification number, year of foundation, jurisdiction (federal, state or municipality) etc.

Data on political boundaries, water bodies, and roads in the Caatinga were acquired through the Instituto Brasileiro de Geografia e Estatística (IBGE). These files had been updated in 2016 with information from the 2010 census. Information about Caatinga Ecoregions, as established by Velloso et al. (2002), was acquired through the NGOs Associação Plantas do Nordeste and The Nature Conservancy of Brazil, co-publishers of the biogeographical classification of Caatinga ecoregions (Velloso et al. 2002).

\section{Data processing}

We used geographical information systems (GIS) to calculate the total area and proportion of protected areas within each Caatinga ecoregion. Where shapefiles were 
available only in the outdated SAD 69 datum, we reprojected them to SIRGAS 2000, the official datum in Brazil since 2015 (see flowchart in Fig. 2). We used the 'Checking Geometry' tool to pinpoint and automatically correct spatial errors such as empty or open polygons or crossed vertices.

To evaluate how much of Caatinga was included in PAs we used the 'Intersect' tool, a geoprocessing tool which clips the extent of a polygon that overlaps with another polygon and generates a new shapefile restricted to the area of intersection between the polygons (in our case PAs and the limits of the Caatinga Domain), maintaining the original data in the attribute table. PAs or parts of PAs occurring inside the polygon of total extent of Caatinga according to the Velloso et al. (2002) limits were extracted with 'Intersect' tool. Thus, after the intersect operation, areas outside the limits of Caatinga were excluded from this study. We exported this database as a new Shapefile (first export - E-1 in Fig. 2). The attribute table for each PA within Caatinga was exported to a '.txt' format and imported to a spreadsheet as the basis for this paper.

Subsequently, the tool 'Single part to multi part' was used to separate the Caatinga ecoregions in eight individual polygons. Then an Intersect of PAs was executed for each ecoregion, generating eight shapefiles of protected areas included in each ecoregion. It is relevant to remember that some PAs extend over more than one ecoregion, which is the reason we exported the E-1 data previously for analysis. For each shapefile of PAs, the area of individual polygons inside individual ecoregions was calculated and added to a new column in the attribute table. In addition, we calculated the area of the polygons of PAs for each Caatinga ecoregion to evaluate the proportion protected by nature reserves.

Before exporting data for individual Caatinga ecoregions (E-2), we loaded our near-final geographical data to the official Brazilian online GIS portal 'i3Geo' for visual verification of our edited dataset against the "official" online geographical data. We discovered that a PA created in 2001 (RPPN Serra das Almas), was missing from the official data downloaded. We manually downloaded the shapefile for this PA and added it to our dataset after executing all procedures described above. A final map of PA distribution across Caatinga ecoregions was then prepared. Metadata for each PA was exported and analysed in a spreadsheet in our supplementary data (Flowchart 2 in Fig. 3).

Table 1. Groups and classes of PA in Brazil.

\begin{tabular}{|c|c|c|c|c|c|}
\hline Groups & Classes by SNUC & Designation Type & Acronym & $\begin{array}{l}\text { IUCN Management } \\
\text { Category }\end{array}$ & $\begin{array}{l}\text { Level of legal protection of } \\
\text { the local biodiversity }\end{array}$ \\
\hline I & Full Protection & $\begin{array}{l}\text { Ecological Station } \\
\text { (Estação Ecológica) }\end{array}$ & ESEC & Ia & Very high \\
\hline I & Full Protection & $\begin{array}{l}\text { Biological Reserve } \\
\text { (Reserva Biológica) }\end{array}$ & REBIO & Ia & Very high \\
\hline I & Full Protection & $\begin{array}{l}\text { [National] Park* } \\
\text { (Parque Nacional) }\end{array}$ & PARNA & II & High \\
\hline I & Full Protection & $\begin{array}{l}\text { Natural Monument } \\
\text { (Monumento Natural) }\end{array}$ & $\mathrm{MN}$ & III & High \\
\hline I & Full Protection & $\begin{array}{c}\text { Wildlife Refuge } \\
\text { (Refúgio de Vida Silvestre) }\end{array}$ & REVIS & III & High \\
\hline II & Sustainable use & $\begin{array}{l}\text { Private National Patrimony Reserve } \\
\text { (Reserva Particular do Patrimônio Natural) }\end{array}$ & RPPN & IV & Moderate/high \\
\hline III & Sustainable use & $\begin{array}{l}\text { [National] Forest* } \\
\text { (Floresta Nacional) }\end{array}$ & FLONA & VI & Moderate \\
\hline III & Sustainable use & $\begin{array}{c}\text { Fauna Reserve } \\
\text { (Reserva de Fauna) }\end{array}$ & REFAU & $\mathrm{n} / \mathrm{a}^{* *}$ & Moderate \\
\hline III & Sustainable use & $\begin{array}{l}\text { Area of Relevant Ecological Interest } \\
\text { (Área de Relevante Interesse Ecológico) }\end{array}$ & ARIE & IV & Moderate \\
\hline III & Sustainable use & $\begin{array}{l}\text { Sustainable Development Reserve } \\
\text { (Reserva de Desenvolvimento Sustentável) }\end{array}$ & RDES & VI & Moderate/Low \\
\hline III & Sustainable use & $\begin{array}{l}\text { Extractive Reserve } \\
\text { (Reserva Extrativista) }\end{array}$ & RESEX & VI & Moderate/Low \\
\hline IV & Sustainable use & $\begin{array}{l}\text { Environmental Protection Area } \\
\text { (Área de Proteção Ambiental) }\end{array}$ & APA & V & Very low \\
\hline
\end{tabular}

Brazilian Law 9985/2000 (Brasil 2000) established 12 types of protected area which are classified in two classes (Full Protection and Sustainable Use). We treated these in four groups for analysis purposes. All Full Protection PAs are placed in Group I, while Sustainable Use PAs are divided in three groups: private reserves as group II; all other Sustainable Use reserves as group III except for APAs which constitute group IV.

*Protected areas which can be implemented also by state or municipal governments and are not strictly "national".

** There is no register of REFAU PAs category implemented in Brazil. Also, not available at IUCN management categories. 
The second phase of analysis started with E-2 (Fig. 3). We grouped the types of $\mathrm{PA}$ in four groups in decreasing order of protection received from Brazilian law as described above.

In some cases, two PAs overlap. This can happen when a PA of higher level of protection (e.g., a national forest or a national park) is created inside a PA of lower level of protection (usually an APA). When a territory was encompassed by two overlapping PAs, we attributed its area only to the PA with the higher level of protection following Table 1 (e.g., the extent of a RPPN inside an APA is counted as RPPN and a National Park inside an APA is counted as a National Park).

A final spreadsheet was elaborated to evaluate the data processed using descriptive statistics, to quantify accumulation curves of number of PAs over time, and accumulation curves of total protected extent over time. We compared our results with those of the most recent comparable study (Hauff 2010) and calculated the differences in PA coverage per ecoregion.

A high-resolution map, a spreadsheet with data from all PAs within Caatinga and the shapefiles with all data processed for this study are made available in our supplementary data at: https://doi.org/10.6084/m9.figshare.13120358.

\section{Management effectiveness}

We analyzed national reports produced by Brazil on management effectiveness of PAs since 2005 (IBAMA \& WWF-Brasil 2007; ICMBIO \& WWF-Brasil 2011; 2017). We sought information which would allow us to compare the management effectiveness of Caatinga PAs in Groups I - IV. We compiled published narrative comments and statistics which compared management effectiveness in different Brazilian domains, comparisons of management effectiveness across PA types, and evidence of change over time.

Completion of protected area management effectiveness evaluations is the only currently available global indicator for management effectiveness (Bacon et al. 2019). These assessments are tracked in the Global Database of Protected Area Management Effectiveness (https://pame. protectedplanet.net/). We downloaded records of completed assessments of Protected Area Management Effectiveness (PAME 2020) for Brazil (IBAMA \& WWF-Brasil 2007).
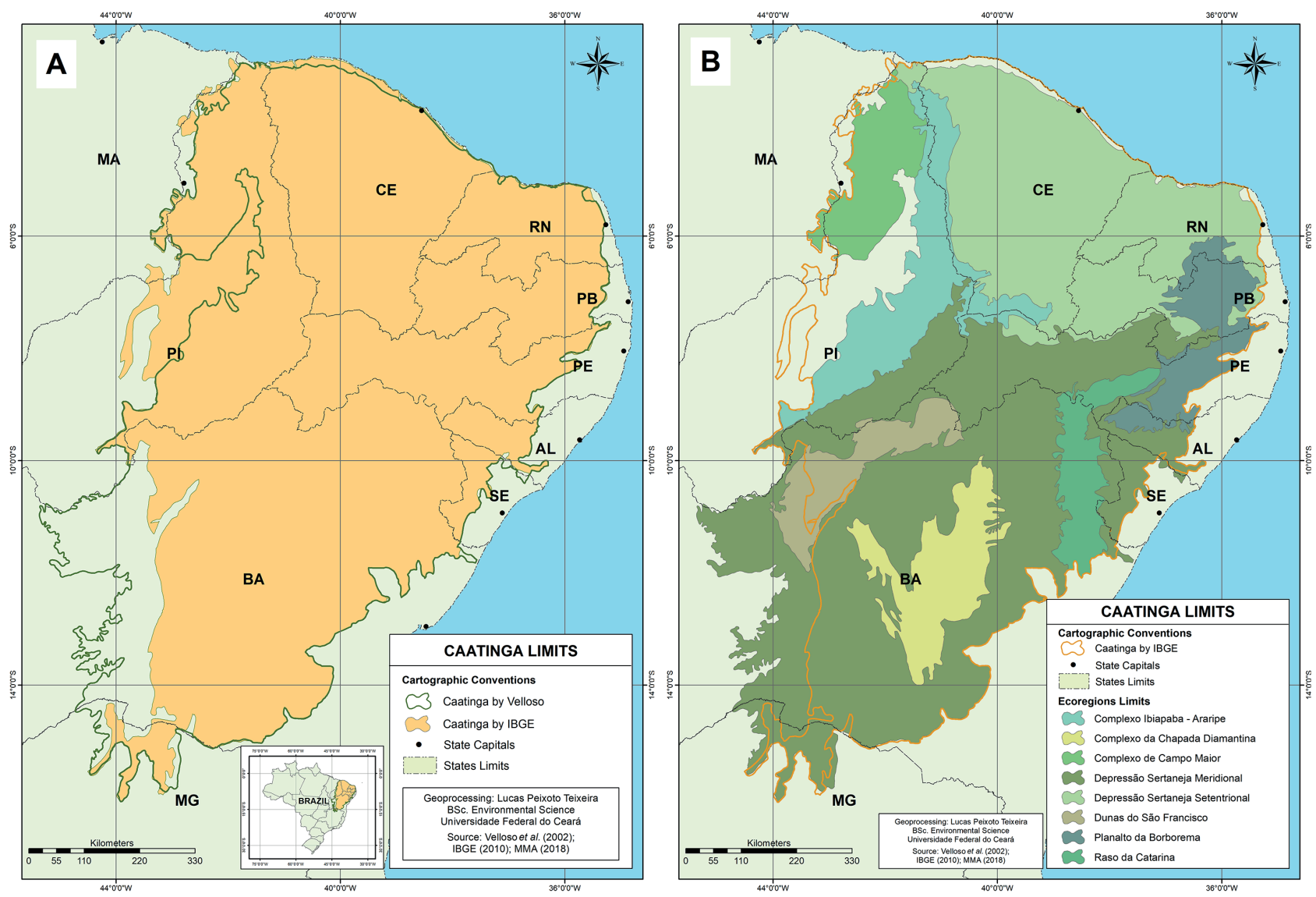

Figure 1. Caatinga Limits. A: Geographical extent of the Caatinga Domain based on overlap between two influential maps: that of the Instituto Brasileiro de Geografia e Estatística (IBGE 2010), brown polygon, and Caatinga Ecoregions map by Velloso et al. (2002), green outline. Velloso's circumscription of Caatinga, adopted in our study, differs from that of IBGE in including the western part of Bahia but excluding an area of central-western Piauí. Codes for Brazilian states: MA - Maranhão; PI - Piauí; CE - Ceará; RN - Rio Grande do Norte; PB - Paraíba; PE - Pernambuco; AL - Alagoas; SE - Sergipe; BA - Bahia; MG - Minas Gerais. B: Ecoregions of Caatinga according to Velloso et al. (2002). 


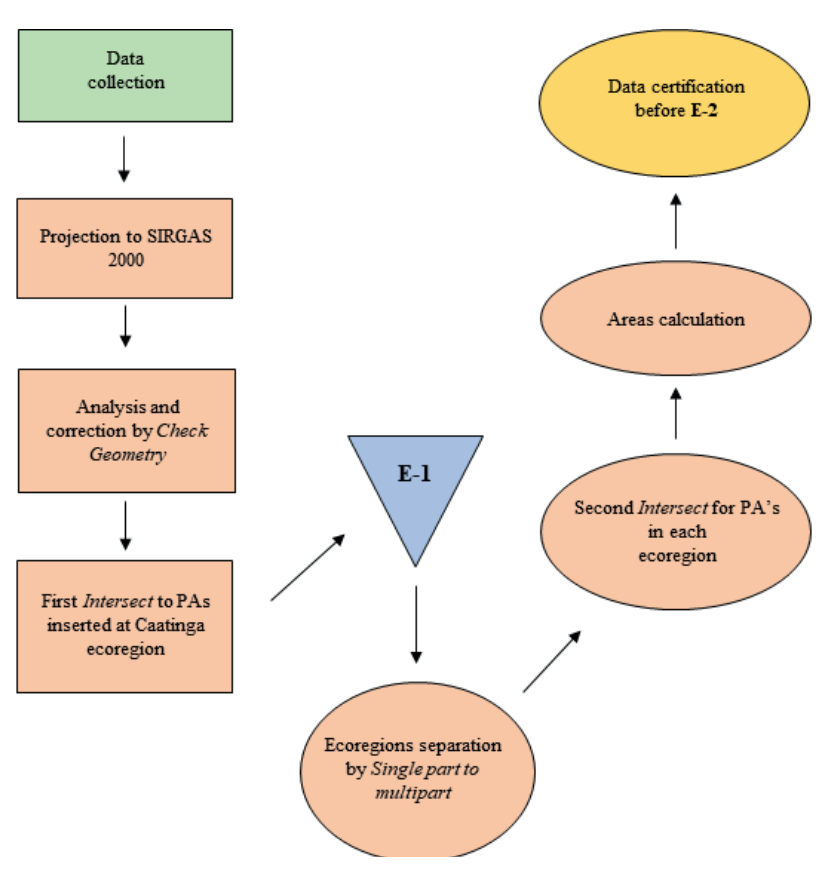

Figure 2. Flowchart 1. Procedures performed to analyze the geographical distribution and extent of Protected Areas within each ecoregion of the Caatinga Phytogeographical Domain, in Brazil.

We cross-referenced this to our list of Caatinga PAs and calculated the proportion of PAs in each of our Groups I-IV for which a management effectiveness evaluation was logged in the PAME database. We used a chi square test to ascertain whether there were differences between Groups I - IV in terms of the proportion of PAs within each group for which a management effectiveness evaluation had been completed.

\section{Results}

\section{PA coverage of Caatinga}

We documented a total of 124 PAs in Caatinga (Fig. 4). They were created between 1946 and 2017 (Fig. 5A) and together their areas sum $6,807,732$ hectares or $7.96 \%$ of the Caatinga total extent as mapped by Velloso et al. (2002). The first PA established in the study area is the Floresta Nacional do Araripe, a reserve located in the south of Ceará state and created in 1946 . The most recently established PA was the Parque Estadual do Cocó, also in Ceará, which was implemented in 2017, the year immediately preceding data acquisition for this study. Beginning in the 1990s, and continuing in the first decade of the 21st century, there was a steady increase in the number of new PAs created, with a reduction in pace in more recent years in both number and total extent of new PAs designated (Fig. 5A-B).

Considering the PAs by group (Fig. 5A), we found that Groups I and II had similar numbers of PAs, each contributing approximately one third of the total number

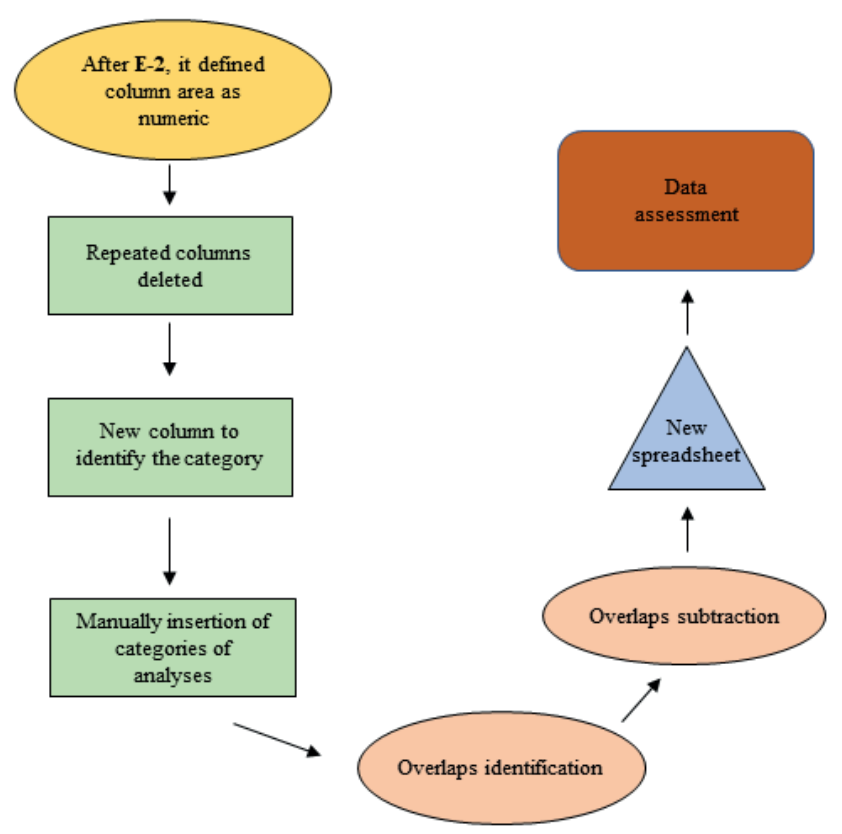

Figure 3. Flowchart 2. Final procedures performed to analyze the geographical distribution and extension of Protected Areas inside each ecoregion of the Caatinga Phytogeographical Domain in Brazil.

of Caatinga PAs: Group I comprised 42 Full Protection sites while Group II encompassed 43 private nature reserves (RPPNs) officially registered in the MMA database. Group IV comprised 27 APAs while in Group III all other Sustainable Use protected areas (RUS) summed to 12 .

Although RPPNs and Full Protection PAs were more numerous, they represented a small proportion of total PA extent (Fig. 5-B). While 6,807,732 hectares of Caatinga had some type of legal protection, APAs (Group IV) were by far the group with the largest spatial extent: 5,610,588 ha. In contrast, Full Protection sites summed to only 1,112,508 ha, RUS 72,476 ha, and RPPN only 12,164 ha. From the 1980 s until 2002 there was a considerable increase in total PA extent. This was achieved by a moderate increase in land protected as Full Protection reserves and a large increase in APAs.

Calculation of the total area protected in each PA group, showed that only $7.96 \%$ of Caatinga is legally protected and only $1.30 \%$ is protected by Full Protection reserves (Tab. 2), which best safeguard biodiversity. Although there was a clear pattern showing the creation of RPPNs increasing steadily during the 21 st century (Fig. 5-A), collectively they represented just $0.01 \%$ of Caatinga (Tab. 2). Sustainable Use reserves in Group III represented a similarly small portion of Caatinga: $0.08 \%$. In contrast APAs collectively represented $6.56 \%$ of the total extent of Caatinga in area.

\section{Ecological representation within Caatinga PAs}

Within Caatinga, ecoregions differed widely in their PA coverage (Fig. 6). Three ecoregions (Complexo de Campo Maior, Complexo da Ibiapaba-Araripe and Dunas do São 
Francisco) had over $17 \%$ of their area encompassed by PAs, reaching Aichi target 11 at least in terms of legally protected area, while the remaining five ecoregions fell far short of this threshold, with total PA coverage per ecoregion ranging from 0.1 to $7.4 \%$ (Tab. 3). However, when PA coverage for ecoregions was considered by PA group, a more complex and concerning picture emerged. In two of the three ecoregions which exceeded the $17 \%$ target, the legally protected area was all or almost all within APAs, the weakest form of protection (99\% for Complexo de Campo Maior, and 100\% for Dunas do São Francisco). Thus the $17 \%$ threshold was exceeded almost exclusively through the recognition of very large APAs. The situation of Complexo da Ibiapaba-Araripe was appreciably better, with $4.5 \%$ of its extent encompassed in Full Protection PAs, placing it in the top three Caatinga ecoregions in terms of Full Protection coverage, along with Complexo da Chapada Diamantina (4.06\%) and Raso da Catarina (5.37\%). No other ecoregions had more than $1 \%$ of their extent within Full Protection reserves.

Comparison of our estimates of PA coverage for Caatinga with those of Hauff (2010) showed striking differences. Despite the seven years which elapsed between the two studies, over which period 35 additional PAs were designated in Caatinga covering a total of 139,203 hectares, our estimate of total PA coverage for Caatinga is lower than Hauff's by $0.44 \%$, equivalent to 376,428 hectares. Comparison of estimates for individual ecoregions revealed apparent overestimates by Hauff (2010) for five of the eight ecoregions (Complexo Campo Maior, Complexo Ibiapaba - Araripe, Depressão Sertaneja Sententrional, Planalto da Borborema, and Raso da Catarina). These discrepancies may be caused by differences in the methodologies or the data sources used by Hauff. It is unclear whether or not Hauff (2010) considered the total extent of PAs that extend beyond the limits of Caatinga; portions of PAs which extend beyond the limits of Caatinga are excluded from our data.

\section{Management effectiveness of Caatinga PAs}

Examination of management effectiveness reports produced by Brazil 2005-17 (IBAMA \& WWF-Brasil 2007; ICMBIO \&WWF-Brasil 2011; 2017) showed that they varied greatly in the ways in which PA types were grouped and in whether data were broken down by domain (termed biome in Brazil), with the result that robust quantitative analyses by PA type by domain were not possible. Further observations on the reports analyzed are presented in Supporting Information.

Analysis of which Caatinga PAs are represented by management effectiveness reports in the Global Database of Protected Area Management Effectiveness showed significant differences in representation of our different groups of Caatinga PAs (chi-squared $=24.318$, $\mathrm{df}=3, \mathrm{p}<<$ 0.001 - see supplementary material for the detailed results). No management effectiveness evaluations were reported for Caatinga RPPNs. Among the other Sustainable Use PAs, the APAs were least likely to have a recent management effectiveness report while Group III (RUS) had relatively high coverage, as did the Full Protection PAs.

\section{Discussion}

Our study of protected areas in the Caatinga combined 2018 data from Brazil's official registry of protected areas, with rigorous GIS analyses to remove duplication and maximize consistency so as to provide an accurate estimate of Brazil's progress towards Aichi target 11 by

Table 2. Total extent (in hectares) and the percentage of the full extent of Caatinga encompassed by protected areas with different level of legal protection.

\begin{tabular}{|c|c|c|c|}
\hline $\begin{array}{c}\text { Classification according to Brazilian law } \\
\text { (Law 9.985/2000) }\end{array}$ & $\begin{array}{c}\text { Groups of protected areas divided by the degree } \\
\text { of safeguard they offer to biodiversity }\end{array}$ & $\begin{array}{c}\text { Area } \\
\text { (hectares) }\end{array}$ & $\begin{array}{c}\% \text { of Caatinga } \\
\text { included }\end{array}$ \\
\hline Full Protection & Group I - Full Protection Areas (PI) & $1,112,504.95$ & $1.30 \%$ \\
\hline Sustainable Use & Group II - Private Reserves (RPPN) & $12,164.39$ & $0.01 \%$ \\
\hline Sustainable Use & Group III- Other Sustainable Use areas except RPPN and APA (RUS) & $72,475.95$ & $0.08 \%$ \\
\hline Sustainable Use & Group IV - Environmental Protection Areas (APA) & $5,610,586.82$ & $6.56 \%$ \\
\hline & Total & $6,807,732.11$ & $7.96 \%$ \\
\hline
\end{tabular}

Table 3. Percentage of each ecoregion protected by SNUC nature reserves for each group.

\begin{tabular}{|c|c|c|c|c|c|}
\hline \multirow{2}{*}{ Ecoregions } & Group I - PI & Group II - RPPN & Group III- RUS & Group IV - APA & \multirow{2}{*}{ Total } \\
\hline & Full Protection & Sustainable Use & Sustainable Use & Sustainable Use & \\
\hline Complexo da Chapada Diamantina & $4.06 \%$ & $0.00 \%$ & $0.15 \%$ & $2.24 \%$ & $6.44 \%$ \\
\hline Complexo de Campo Maior & $0.15 \%$ & $0.00 \%$ & $0.00 \%$ & $17.13 \%$ & $17.26 \%$ \\
\hline Complexo Ibiapaba-Araripe & $4.50 \%$ & $0.04 \%$ & $0.55 \%$ & $16.28 \%$ & $21.37 \%$ \\
\hline Dunas do São Francisco & $0.00 \%$ & $0.00 \%$ & $0.00 \%$ & $53.14 \%$ & $53.14 \%$ \\
\hline Depressão Sertaneja Meridional & $1.00 \%$ & $0.01 \%$ & $0.05 \%$ & $2.74 \%$ & $3.80 \%$ \\
\hline Depressão Sertaneja Setentrional & $0.18 \%$ & $0.03 \%$ & $0.03 \%$ & $2.26 \%$ & $2.51 \%$ \\
\hline Planalto da Borborema & $0.07 \%$ & $0.00 \%$ & $0.00 \%$ & $0.05 \%$ & $0.12 \%$ \\
\hline Raso da Catarina & $5.37 \%$ & $0.00 \%$ & $0.00 \%$ & $2.02 \%$ & $7.39 \%$ \\
\hline
\end{tabular}


Lucas Peixoto Teixeira, Eimear Nic Lughadha,

Marcus Vinicius Chagas da Silva and Marcelo Freire Moro

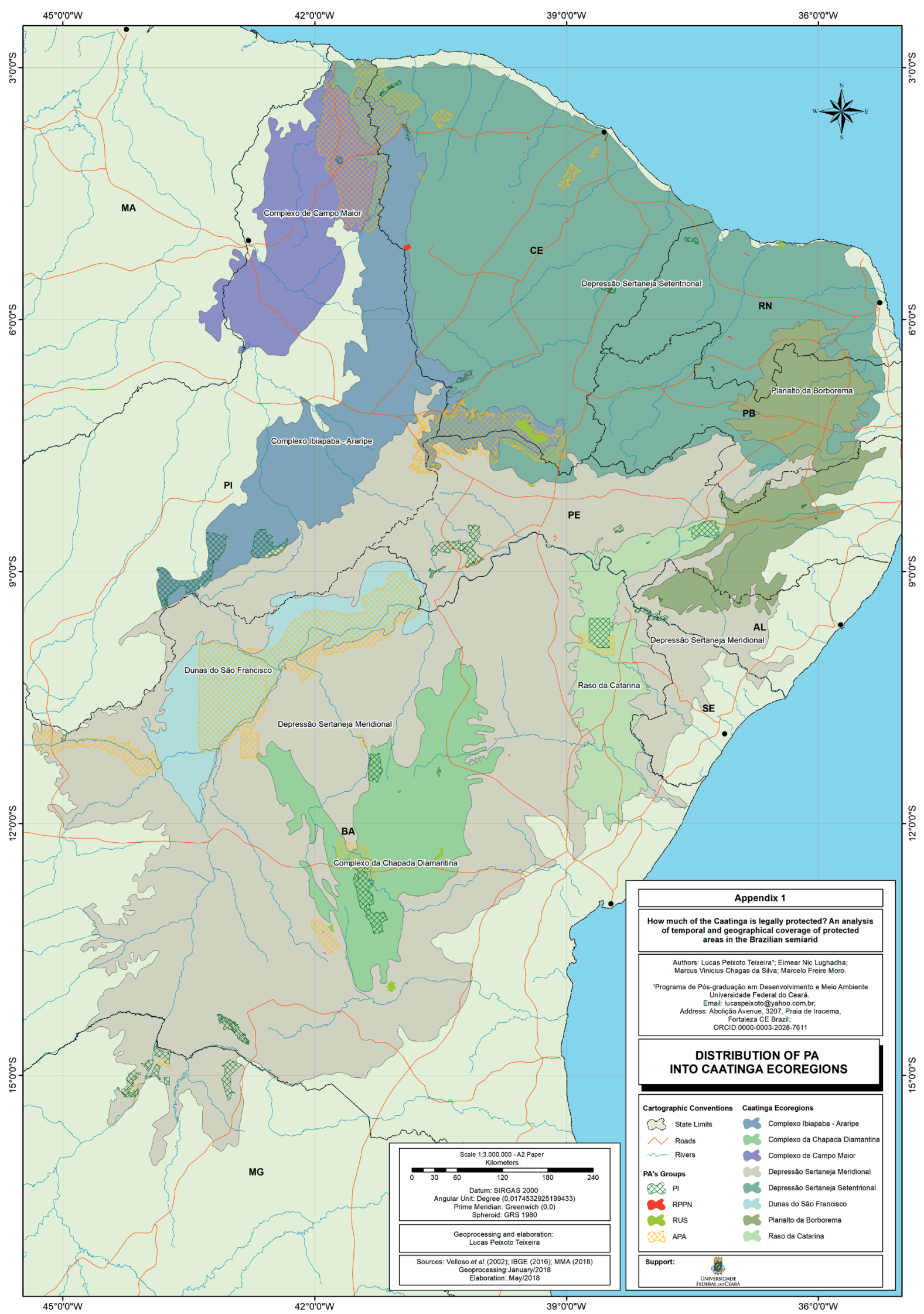

Figure 4. Distribution of Protected Areas in Caatinga ecoregions. This map is available in high resolution in our supplementary files. 
How much of the Caatinga is legally protected? An analysis of temporal and geographical coverage of protected areas in the Brazilian semiarid region
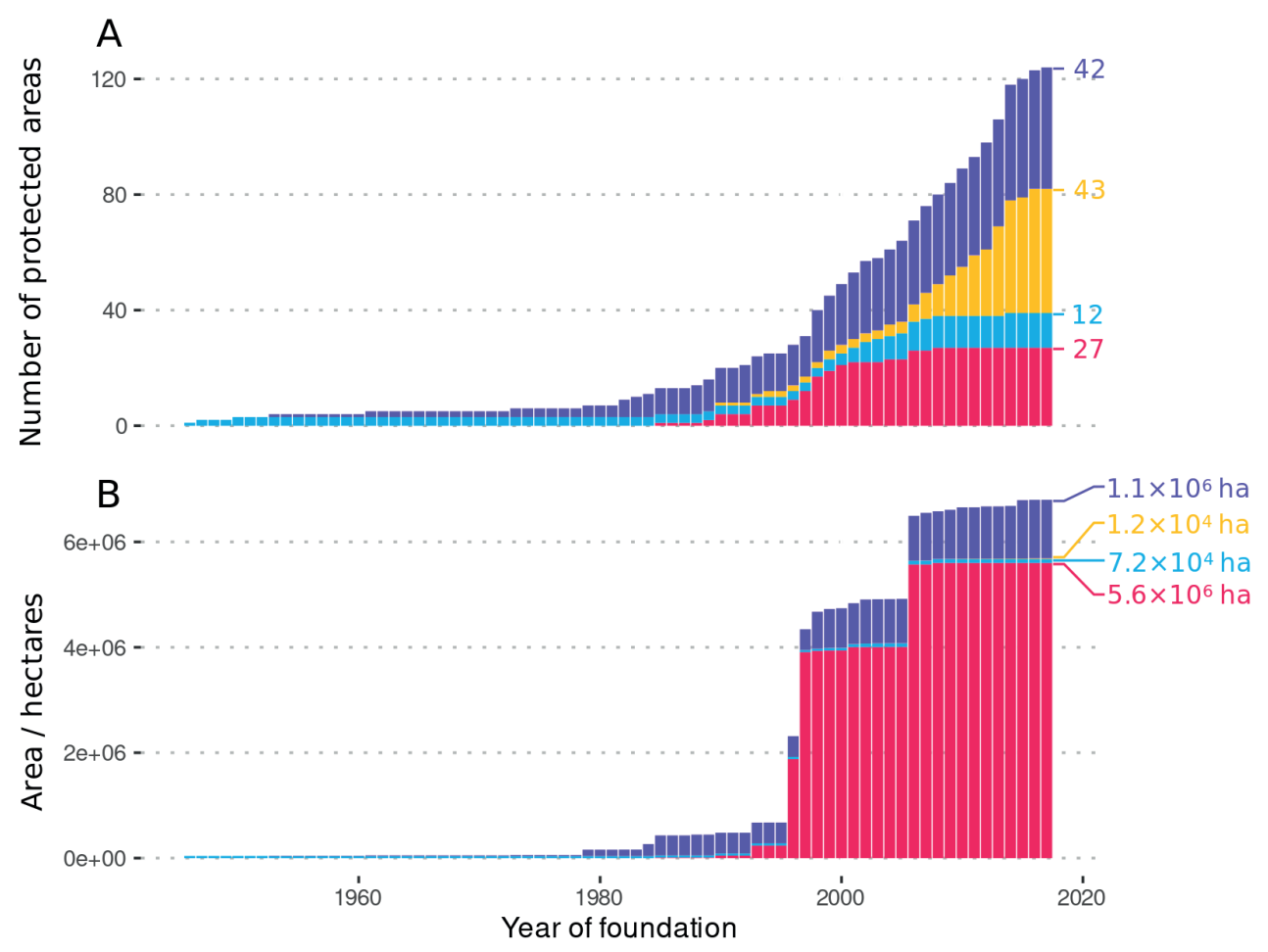

Group I - PI Group II - RPPN Group III - RUS

Group IV - APA

Figure 5. A: Cumulative plot of the number of Protected Areas created in Caatinga from the first one in 1946 to 2017 . B: Cumulative plot of total protected geographical extent (in hectares) in Caatinga from 1946 to 2017.

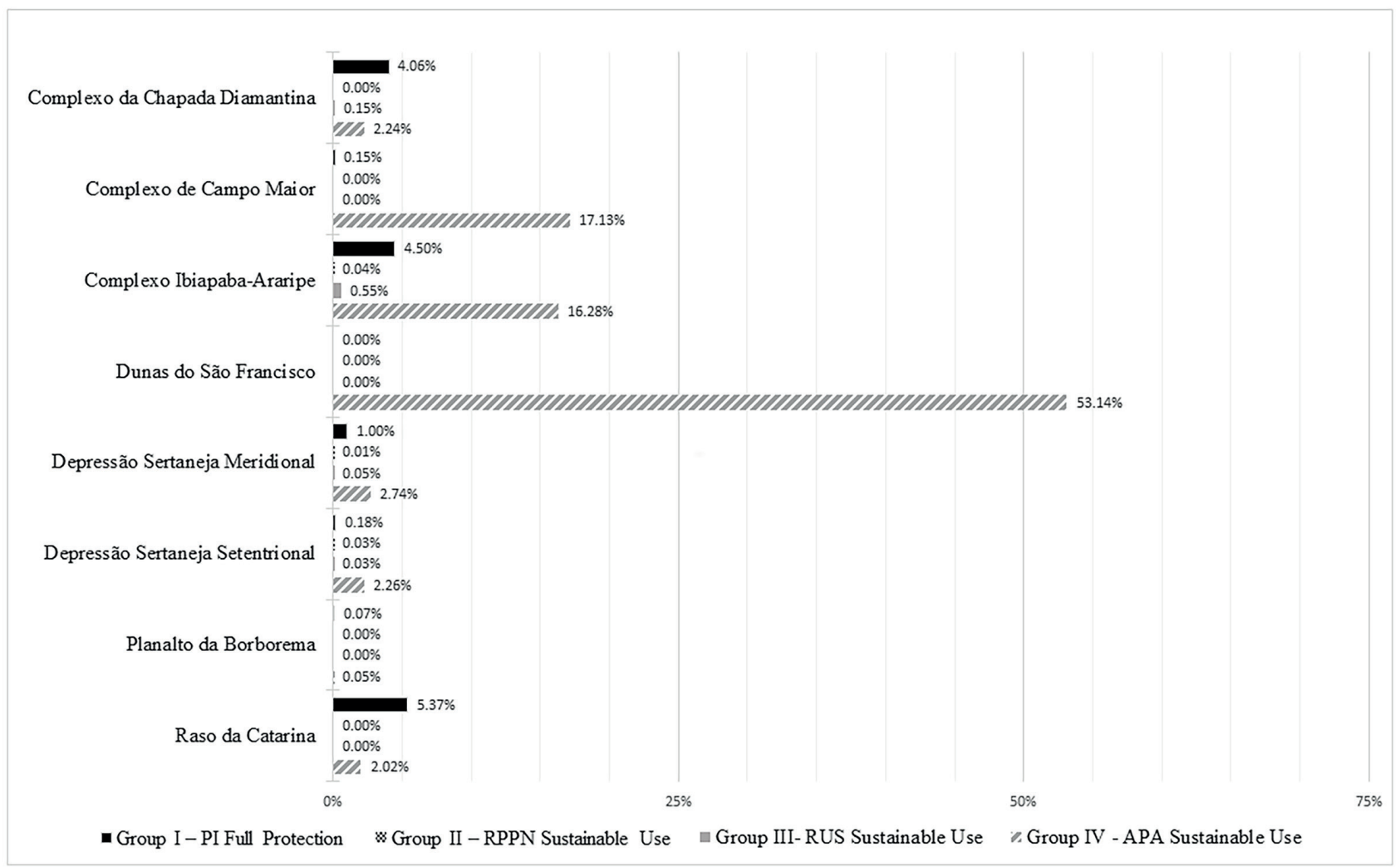

Figure 6. Graph showing the percentage of each Caatinga's ecoregion protected by SNUC nature reserves for each group. 
achieving 17\% PA coverage for terrestrial ecosystems. Drilling down into the individual ecoregions and different types of legally protected area within Caatinga allowed us to evaluate ecological representation and consider management effectiveness. On all three counts: coverage, ecological representation and effective management, we conclude that Brazil is far from meeting the Aichi 11 target with respect to Caatinga.

The target of achieving $17 \%$ protected area coverage for Caatinga dates from 2013 when Brazil set new National Targets based on the Aichi global targets. With hindsight, that decision could be interpreted as a triumph of optimism over experience, since Brazil had recently failed to meet the earlier target of $10 \%$ protected area coverage by 2010 . Furthermore, a national analysis based on 2013 data (Brazil Ministry of the Environment 2015) showed negligible growth in total geographical area protected since 2009. Caatinga PA coverage was estimated at $7.5 \%$ at that date. Comparison with our estimate of just under $8 \%$ four years later illustrates the glacial pace of progress and inspired little hope that a doubling of PA coverage could be delivered by 2020 , not least because the prevailing economic and political climate is much less conducive to biodiversity conservation now than in the early years of the millennium (Magnusson et al. 2018).

Notwithstanding the evidence presented above, Brazil's 5th National Report to the Convention on Biological Diversity (Brazil - Ministry of the Environment 2015) provides some insights as to how the $17 \%$ target for 2020 could be argued to be realistic, at least in terms of headline measure of coverage. Crucially, unlike Brazil's 2010 National Target, National Targets adopted by Brazil in 2013 in response to the global Aichi targets were based on a new and more inclusive method of quantifying the total area considered to be protected. In addition to the Full Protection and Sustainable Use PAs recognized under SNUC and included in our analyses, Brazil also intended to count toward the target other areas which 'contribute to nature protection' such as indigenous lands, quilombola territories, permanent preservation areas (including riparian preservation areas and hilltop preservation areas), and legal reserves in private properties - even though permanent preservation areas and legal reserves are admitted by the MMA to be 'less strict or effective' (Brazil - Ministry of the Environment 2015).

Brazil's 2012 Forest Code (FC) (Brasil 2012) introduced major changes to the definition of permanent preservation areas and legal reserves. These changes in PA accounting approach prompted an ongoing massive nationwide initiative to document and geo-reference millions of rural properties, varying portions of which might qualify as protected areas in the broadest sense, including hilltops and riparian areas, many of which are already deforested and will serve to increase "protected areas" only in theory, without a real effect on the ground. Estimating the full impact of this new and more inclusive accounting approach is beyond the scope of our study. Detailed modelling of the impacts of the Forest Code suggest that much of the Caatinga is fully compliant with the new thresholds and that the FC will, in all likelihood, allow additional deforestation in the Caatinga (Soares-Filho et al. 2014). Thus, ironically, FC implementation could allow Brazil to meet its 2013 National Target corresponding to global Aichi Target 11 in theory, declaring a greatly increased proportion of the Caatinga to be "protected" (including already deforested areas), while also legalizing further deforestation.

However, when Brazil's $6^{\text {th }}$ National Report (Brazil Ministry of the Environment 2020) reported progress towards Target 11, based on a data assessment undertaken in May 2018, Target 11 was reported as not achieved despite including indigenous lands as an extra category although its progress was classified as "on track to achieve target" (Brazil - Ministry of the Environment 2020). The idea presented in the $5^{\text {th }}$ report to count private legal reserves and private permanent preservation areas as "protected", even when they are already deforested, appears to have been reconsidered, as the Additional Information supporting the 2020 Target 11 report allows for accounting for Target 11 to include 'other areas-based effective conservation measures, as long as they maintain native vegetation'. However, the manner in which such OMECs will be considered to contribute to Target 11 was reported to be 'still under technical discussion' (Brazil - Ministry of the Environment 2020).

To address the question as to whether the existing protected area network for Caatinga encompasses an ecologically representative set of areas, we quantified and characterized coverage across the eight ecoregions of Caatinga proposed by Velloso et al. (2002) and found significant heterogeneity in the extent of coverage in each ecoregion and the level of protection provided. Only three of the eight ecoregions reached the $17 \%$ target in terms of simple coverage and for two of these virtually all (99-100\%) of that coverage was in the form of APAs, by far the least effective form of protected area. For example, the Dunas do São Francisco, an ecoregion with a considerable number of endemic species (Rodrigues \& Santos 2008; Queiroz et al. 2017), does not have any Full Protection reserves (Tab. 2). More encouragingly, the ecoregion with the largest proportion protected by Full Protection reserves is the Raso da Catarina, an ecoregion with sandy soils and their associated endemic plants and burrowing, fossorial animals (Rodrigues \& Santos 2008; Queiroz et al. 2017).

Our choice of the Velloso et al. (2002) ecoregion schema as the framework for our ecological representation analysis, rather than the Olson et al. (2001) system, was based on the rapidly increasing body of scientific evidence indicating that the heterogeneity and complexity of the biodiversity of the Caatinga domain merits a more sophisticated treatment than simply designating it as a single ecoregion 
(Moro et al. 2016). Much of this new evidence has been obtained and synthesized over the past two decades and so would not have been available to Olson et al. (2001) (eg: Rodrigues 1996; Rodrigues \& Santos 2008; Guedes et al. 2014; Werneck et al. 2015; Moro et al. 2016; Souza et al. 2016; Queiroz et al. 2017; Fernandes et al. 2020) when their ecoregions proposal was in development. Recent studies have shown differences in the flora of different subregions within Caatinga and have recorded the existence of endemic genera and endemic species of both plants and animals in each individual Caatinga ecoregion (Velloso et al. 2002).

Although the Velloso et al. (2002) ecoregions are widely recognized and applied, they are by no means the only evidence-based approach to a spatial subdivision of Caatinga into regions that reflect differences in biodiversity. An alternative subdivision of Caatinga might provide a different perspective on the extent to which the current protected area network is ecologically representative of the Caatinga domain as a whole. For example, a recent, data-driven phytogeographic regionalization of the Caatinga recognized nine floristic groups considered to show little overlap with previous Caatinga classifications (Silva \& Sousa 2018). An analysis of protected area coverage within these groups could provide an interesting and informative contrast to our study.

A limitation of our study is that our quantitative approaches were appropriate to the evaluation of total extent of PA coverage in Caatinga and the degree of ecological representation of the current PAs but less suited to the evaluation of management effectiveness (Leverington et al. 2010; OECD 2015). Effective management of protected areas is widely recognized as one of the key aspects of Target 11 (Coad et al. 2013) and a challenge which the majority of countries fail to meet (Ferreira et al. 1999; Hockings et al. 2006). Over the past two decades, evaluation of management effectiveness has emerged and developed as a discipline in its own right. Brazilian scientists were among the pioneers in this field (Ervin 2003) and continue to be active in the development of protocols that can assess effective and equitable management in the implementation of Aichi Target 11 (ICMBIO \& WWF-Brasil 2011). Brazil was an early adopter of the Rapid Assessment and Prioritization of Protected Area Management (RAPPAM) Methodology, which was developed specifically for use on a system-wide scale (IBAMA \& WWF-Brasil 2007; ICMBIO \& WWF-Brasil 2011; 2017).

More recently, following the establishment of Instituto Chico Mendes de Conservação da Biodiversidade (ICMBio), a second, complementary system has been developed: System for Analysis and Monitoring of Management (SAMGe) (ICMBIO \& WWF-Brasil 2011). Comparative analysis of reports based on data from RAPPAM and/or SAMGe proved challenging in our study, not least due to differences in how the different PA types were grouped over time and the extent to which the reports included breakdowns by domain (termed biome). Despite difficulties in comparisons and in identification of change over time, careful reading leaves little room for doubt that there is cause for concern regarding the PA network for Caatinga and, in particular, the predominance within it of APAs (see List in supplementary material: https://doi.org/10.6084/ m9.figshare.13120358).

Overall, these reports (IBAMA \& WWF-Brasil 2007; ICMBIO \& WWF-Brasil 2011; 2017) provide little reassurance that the areas which comprise the PA network to represent Caatinga are effectively managed. Although the threshold values of $17 \%$ to meet the Convention on Biological Diversity's Aichi biodiversity target 11 appear to have been met for some ecoregions, the fact that so much of the area of the network comprises APAs is a clear indication that, far from being protected, the biodiversity in most areas is suffering the adverse effects of increased pressure from resource use and human occupation. Furthermore, the very limited improvements in management effectiveness achieved during a period of economic growth in Brazil 2005-10 (IBAMA \& WWF-Brasil 2007), combined with the low return rate from Caatinga PAs in the latest round of monitoring in particular for Caatinga APAs (Fonseca et al. 2018), leaves little room for doubt that the biodiversity in much of the Caatinga PA network is at high risk of decline, local extinction, and even global extinction in the case of species endemic to Caatinga.

While our study shows a wide gap between aspiration and achievement in Brazil's progress with effective protection of Caatinga, it is important not to understate the very significant scientific and practical steps that have been taken toward that goal in recent years. A notable milestone was the determination of 282 priority areas for conservation, sustainable use and shared benefits of Caatinga biodiversity, enshrined in Brazilian law in 2016 (Fonseca et al. 2018). This represented the culmination of a series of participatory systematic conservation planning workshops reported in detail by Fonseca et al. (2018). Although these authors acknowledge that the economic climate is not conducive to immediate creation of new protected areas, even in the subset of 53 priority areas which they identified as the best opportunities for proactive conservation, they identify potential ways forward in collaboration with industry, international NGOs and financial institutions.

The almost inevitable hiatus between designation of priority areas for Caatinga conservation and their implementation represents an ongoing risk to the Caatinga domain and a frustration to the many researchers and practitioners who have invested so much energy and time to reach this point. However, the hiatus can also be seen as an opportunity, even when resources for science and conservation are scarce. Low-budget conservation research projects, such as that described in this paper, based only on data in the public domain, have the potential to provide valuable insights into current conservation 
questions. The 282 priority areas identified in 2016 (Fonseca et al. 2018) were selected based on a combination of 691 conservation targets, the majority being species of plants and birds for which data on conservation status was available. Most Caatinga species still lack formal extinction risk assessments which would allow their inclusion in future studies. The increasing availability of online risk evaluation tools, training, and occurrence data has rendered extinction risk assessment - once a highly specialist activity - more accessible, achievable and affordable (Bachman et al. 2019), even within the timescale of undergraduate or postgraduate student projects. And the increasingly availability of smartphones offers exciting opportunities to involve local people in citizen science projects, monitoring their local biodiversity and proactively searching for species which are considered to be at risk of extinction.

Actions at local level will need to be complemented by action at regional, national and international level if Brazil is to be encouraged and supported to meet its commitments under the Convention on Biological Diversity. Ultimately, the ongoing degradation and destruction of Brazil's unique Caatinga phytogeographical domain is a matter of global concern, since many species and genera characteristic of Caatinga are not found elsewhere (Queiroz et al. 2017). Their loss represents a significant opportunity cost, not only in terms of the loss of unique evolutionary history before it has been studied, but also in practical terms as the loss of organisms which are the products of millions of years of evolution in and adaptation to arid environments. Their individual adaptations, which provide the resilience to allow them to persist in their extreme environment, are a resource likely to be of increasing interest and value to human populations as the extent of semi-arid environments increases under climate change.

\section{Acknowledgements}

The authors thank the Instituto de Ciências do Mar (Labomar) of the Universidade Federal do Ceará (UFC), all professors and colleagues from UFC's Environmental Science course who supported this project; Barnaby Walker (RBG Kew) who redrew Figure 5 and two anonymous reviewers whose constructive comments helped us to improve this treatment. LP Teixeira thanks the Bentham-Moxon Trust for a grant awarded to him for a study visit to Royal Botanic Gardens, Kew to discuss these results with ENL.

\section{References}

Ab’Sáber AN. 1974. O domínio morfoclimático semiárido das Caatingas brasileiras. São Paulo, Universidade de São Paulo, Instituto de Geografia.

Ab’Sáber AN. 2003. Os domínios de natureza no Brasil: potencialidades paisagísticas. vol. II. Cotia, SP, Ateliê Editorial.

Antongiovanni M, Venticinque EM, Fonseca CR. 2018. Fragmentation patterns of the Caatinga drylands. Landscape Ecology 33: 1353-1367.

Bachman SP, Field R, Reader T, et al. 2019. Progress, challenges and opportunities for Red Listing. Biological Conservation 234: 45-55.

Bacon E, Gannon P, Stephen S, et al. 2019. Aichi Biodiversity Target 11 in the like-minded megadiverse countries. Journal for Nature Conservation 51: 125723. doi: 10.1016/j.jnc.2019.125723

Banda K, Delgado-Salinas A, Dexter KG, et al. 2016. Plant diversity patterns in neotropical dry forests and their conservation implications. Science 353: 1383-1387.

Brasil. 2000. SNUC: Sistema Nacional de Unidades de Conservação da Natureza: Lei no. 9.985, de 18 de Julho de 2000. Brasília, Ministério do Meio Ambiente. http://www.planalto.gov.br/ccivil_03/leis/19985. htm. 23 Jun. 2021.

Brasil. 2012. Lei 12.651 de 25 de maio de 2012. Presidência da República. Casa Civil. Subchefia para Assuntos Jurídicos. http://www.planalto. gov.br/ccivil_03/_ato2011-2014/2012/lei/112651.htm. 23 Jun. 2021.

Brasil. 1988. Constituição da República Federativa do Brasil de 1988. Brasília, Senado Federal, Centro Gráfico. http://www.planalto.gov. br/ccivil_03/constituicao/constituicao.htm. 23 Jun. 2021.

Brazil - Ministry of the Environment. 2015. Fifth National Report to the Convention on Biological Diversity: Bbrazil. Brasília, Ministério do Meio Ambiente. https://www.cbd.int/doc/world/br/br-nr-05-en.pdf.

Brazil - Ministry of the Environment. 2020. 6th National Report to the Convention on Biological Diversity. Brasília, Ministério do Meio Ambiente. https://chm.cbd.int/database/record?documentID=249832. 23 Jun. 2021.

Castelletti CHM. 2003. Estratégias para Conservação da Biodiversidade. Ecologia e Conservação da Caatinga 19: 719-734.

CBD - Convention on Biological Diversity. 2010. The Strategic Plan for Biodiversity 2011-2020 and the Aichi Biodiversity Targets COP 10 Decision X/2. https://www.cbd.int/decision/cop/?id=12268. 23 Jun. 2021.

Coad L, Leverington F, Burgess ND, et al. 2013. Progress towards the CBD protected area management effectiveness targets. Parks 19: 13-24.

Ervin J. 2003. Rapid Assessment of Protected Area Management Effectiveness in Four Countries. BioScience 53: 833-841.

Fernandes MF, Cardoso D, Queiroz LP. 2020. An updated plant checklist of the Brazilian Caatinga seasonally dry forests and woodlands reveals high species richness and endemism. Journal of Arid Environments 174: 104079. doi: 10.1016/j.jaridenv.2019.104079

Ferreira LV, Lemos de Sá RM, Buschbacher R, Batmanian G, Bensusan NR, Costa CL. 1999. Protected areas or endangered spaces. WWF's Report on the Degree of Implementation and the Vulnerability of Brazilian Federal Conservation Areas. Brasília, WWF-Brasil.

Fonseca CR, Antongiovanni M, Matsumoto M, et al. 2018. Conservation opportunities in the Caatinga. In: Silva JMC, Leal IR, Tabarelli M. (eds.) Caatinga: The Largest Tropical Dry Forest Region in South America. Cham, Springer International Publishing. p. 429-443.

Gannon P, Seyoum-Edjigu E, Cooper D, et al. 2017. Status and pro spects for achieving aichi biodiversity target 11: Implications of national commitments and priority actions. Parks 23: 13-26.

Guedes TB, Nogueira C, Marques OAV. 2014. Diversity, natural history, and geographic distribution of snakes in the Caatinga, Northeastern Brazil. Zootaxa 3863: 1-93.

Hauff SN. 2010. Representatividade do Sistema Nacional de Unidades de Conservação na Caatinga. Brasília, Programa das Nações Unidas Para o Desenvolvimento, Ministério do Meio Ambiente - MMA.

Hockings M, Stolton S, Leverington F. 2006. Evaluating effectiveness : a framework for assessing management effectiveness of protected areas., 2nd. edition. Cambridge, UK, International Union for Conservation of Nature - IUCN.

IBAMA, WWF-Brasil. 2007. Efetividade de gestão das unidades de conservação federais do Brasil. http://www.icmbio.gov.br/portal/ images/stories/documentos/2\%20-\%20o\%20que\%20fazemos\%20 -\%20efetividade\%20da\%20gesto\%20de\%20ucs\%20-\%20doc_ efetividade\%20de\%20gesto\%20das\%20ucs\%20federais\%20do\%20 brasil\%202007.pdf. 


\section{How much of the Caatinga is legally protected? An analysis of temporal and geographical coverage of protected areas in the Brazilian semiarid region}

IBGE - Instituto Brasileiro de Geografia e Estatística. 2004. Mapa de biomas do Brasil: primeira aproximação. https://www.ibge.gov.br/ geociencias/downloads-geociencias.html. 23 Jun. 2021.

IBGE - Instituto Brasileiro de Geografia e Estatística. 2010. Censo Brasileiro de 2010. Rio de Janeiro, IBGE, 2010. https://censo2010.ibge.gov. br/. 23 Jun. 2021.

ICMBIO, WWF-Brasil. 2011. Efetividade de gestão as unidades de conservação federais: Avaliação comparada das aplicações do método Rappam nas unidades de conservação federais, nos ciclos 2005-06 e 2010. Brasília. https://www.icmbio.gov.br/portal/images/stories/ comunicacao/downloads/relatrio\%20rappam\%202005\%20x\%20 2010\%20-\%20verso\%20integral.pdf.

ICMBIO, WWF-Brasil. 2017. Avaliação Da Gestão Das Unidades De Conservação: Métodos Rappam (2015) e Samge (2016). https:// d3nehc6yl9qzo4.cloudfront.net/downloads/avaliacao_da_gestao_ das_ucs_rappam_2015_samge_2016_pdf

Juffe-Bignoli D, Burgess ND, Bingham H, et al. 2014. Protected Planet Report 2014. Cambridge, UK, UN Environment Programme World Conservation Monitoring Centre - UNEP-WCMC.

Leal IR, Silva JMC, Tabarelli M, Lacher TE. 2005. Changing the course of biodiversity conservation in the Caatinga of Northeastern Brazil del Noreste de Brasil. Conservation Biology 19: 701-706.

Leverington F, Costa KL, Pavese H, et al. 2010. A global analysis of protected area management effectiveness. Environmental Management 46: 685-698

Magnusson WE, Grelle CEV, Marques MCM, et al. 2018. Effects of Brazil's political crisis on the science needed for biodiversity conservation. Frontiers in Ecology and Evolution 6: 163. doi: 10.3389/ fevo.2018.00163

Miles L, Newton AC, DeFries RS, et al. 2006. A global overview of the conservation status of tropical dry forests. Journal of Biogeography 33: 491-505

MMA - Ministério do Meio Ambiente. 2018. Unidades de Conservação. Cadastro Nacional de Unidades de Conservação (CNUC/MMA). http:// mapas.mma.gov.br/geonetwork/srv/br/metadata.show?id=1250. 29 Jan. 2018

Moro MF, Araújo FS, Rodal MJN, Martins FR. 2015. Síntese dos estudos florísticos e fitossociológicos realizados no semiárido brasileiro. In: Eisenlohr PV, Felfili JM, Melo MMRF, Andrade LA, Neto JAAM. (eds.) Fitossociologia no Brasil :Métodos e Estudos de Casos. Vol. II. Viçosa, Editora da Universidade Federal de Viçosa. p. 412-451.

Moro MF, Nic Lughadha E, Araújo FS, Martins FR. 2016. A Phytogeographical Metaanalysis of the Semiarid Caatinga Domain in Brazil. Botanical Review 82: 91-148.

Nimer E. 1972. Climatologia da região Nordeste do Brasil. Introdução à climatologia dinâmica. Revista Brasileira de Geografia 34: 3-51.

OECD. 2015. OECD Environmental Performance Reviews: Brazil 2015. https://edisciplinas.usp.br/pluginfile.php/3204827/mod_folder/ content/0/OECD\%20Environmental\%20Performance\%20Review\%20 of\%20Brazil\%202015.pdf?forcedownload=1. 12 Dec. 2020.

Olson DM, Dinerstein E, Wikramanayake ED, et al. 2001. Terrestrial
Ecoregions of the World: A New Map of Life on Earth. BioScience 51: 933-938.

PAME - Protected Area Management Effectiveness. 2020. Global Database on Protected Area Management Effectiveness. https://pame. protectedplanet.net/.12 Dec. 2020.

Pennington RT, Prado DE, Pendry CA. 2000. Neotropical seasonally dry forests and Quaternary vegetation changes. Journal of Biogeography 27: 261-273.

Queiroz LP, Cardoso D, Fernandes MF, Moro MF. 2017. Diversity and evolution of flowering plants of the Caatinga Domain. In: Silva JMC, Leal IR, Tabarelli M. (eds.) Caatinga: The Largest Tropical Dry Forest Region in South America. Cham, Springer International Publishing. p. 23-63.

Rizzini CT. 1963. Nota prévia sobre a divisão fitogeográfica do Brasil. Separata da Revista Brasileira de Geografia, Instituto Brasileiro de Geografia e Estatística, Conselho Nacional de Geografia. https://biblioteca.ibge. gov.br/visualizacao/periodicos/115/rbg_1963_v25_n1.pdf

Rodrigues MT, Santos EM. 2008. A new genus and species of eyelid-less and limb reduced gymnophthalmid lizard from northeastern Brazil (Squamata, Gymnophthalmidae). Zootaxa 1873: 50-60.

Rodrigues MT. 1996. Lizards, Snakes, and Amphisbaenians from the Quaternary Sand Dunes of the Middle Rio Sao Francisco, Bahia, Brazil. Journal of Herpetology 30: 513-523.

Sampaio E, Giulietti A, Virgílio J, Gamarra-Rojas C. 2002. Vegetação \& flora da caatinga. Recife, Associção Plantas do Nordeste, Instituto de Conservação Ambiental.

Santos JC, Leal IR, Almeida-Cortez JS, et al. 2011. Caatinga: The scientific negligence experienced by a dry tropical forest. Tropical Conservation Science 4: 276-286.

Silva AC, Souza AF. 2018. Aridity drives plant biogeographical sub regions in the Caatinga, the largest tropical dry forest and woodland block in South America. PLOS ONE 13: e0196130. doi: 10.1371/journal. pone. 0196130

Soares-Filho B, Rajão R, Macedo M, et al. 2014. Cracking Brazil's Forest Code Supplemental. Science 344: 363-364.

Souza EB, Miguel LM, Cabral EL, et al. 2016. Borreria apodiensis (Rubiaceae: Spermacoceae), a new species from Ceará and Rio Grande do Norte, Brazil. Acta Botanica Brasilica 10: 0102-33062016abb0014. doi: 10.1590/0102-33062016abb0014

Vanzolini PE, Ramos-Costa AMM, Vitt LJ. 1980. Répteis das caatingas. Rio de Janeiro, Academia Brasileira de Ciências.

Velloso AL, Sampaio EVSB, Pareyn FGC. 2002. Ecorregiões propostas para o bioma da Caatinga. Recife, Associação Plantas do Nordeste, Instituto de Conservação Ambiental The Nature Conservancy do Brasil.

Werneck FP, Leite RN, Geurgas SR, Rodrigues MT. 2015. Biogeographic history and cryptic diversity of saxicolous Tropiduridae lizards endemic to the semiarid Caatinga. BMC Evolutionary Biology 15: 1-24

Zappi DC, Ranzato Filardi FL, Leitman P, et al. 2015. Growing knowledge: An overview of Seed Plant diversity in Brazil. Rodriguésia 66: 10851113. 